\title{
Shocks and Household Debt in South Africa: A Variance Decomposition and GIRF Analysis
}

\author{
Christelle Meniago \\ North-West University, Department of Economics, \\ E-mail address: meniagochristelle@yahoo.com; \\ Cell: +27 78436 9966, Fax: +27 0183892090 \\ Janine Mukuddem-Petersen \\ North-West University, Graduate School of Business and Government Leadership (GSBGL), \\ E-mail address: JanineMukuddemPetersen@nwu.ac.za \\ Telephone +27 018389 2615; Fax: +27 0183892090 \\ Mark. A. Petersen \\ North-West University, Faculty of Commerce and Administration, \\ E-mail address: MarkPetersen@nwu.ac.za \\ Telephone +27 018389 2622; Fax: +27 0183892090.
}

Gisele Mah

North-West University Department of Economics,

E-mail address: Giselemah@yahoo.co.uk

Cell: +27 71970 9381, Fax: +27 0183892090

Doi:10.5901/mjss.2013.v4n3p379

\section{Abstract}

A crucial boost in the household debt to income ratio was experienced among South African households since the incident of the 2007-2008 US subprime mortgage crisis which later plummeted into the 2008-2009 financial crisis. The key focus of this paper is to investigate how the South African household debt might respond to shocks over a significant time horizon. We analysed the data of seven real macroeconomic variables from 1985 Q1 to 2012 Q1. The Variance Decomposition and the Generalized Impulse Response Function analyses are respectively utilized over a time horizon of five years (20 quarters) to investigate the contributions of each variable in explaining the variation in household debt levels and to assess the impact of household debt to various shocks. The statistical software package EViews 7 is used to conduct the variety of tests used in this study. The outcome of the Variance Decomposition reveals that disparities in the level of household debt in South Africa can be mostly elucidated by contributions in house prices, household income, gross domestic product and prime rate. Vis-à-vis the GIRF analysis, the outcome supports the findings of a significant positive response of household debt to a shock from house prices and household consumption. These outcomes reflect the expectations from the theory of the life cycle hypothesis. In regards to the accuracy and consistency of our analysis, we support its use to assist decision making vis-à-vis lowering household debt levels in the South African economy.

Keywords: Financial crisis, Household indebtedness, Variance Decomposition, Generalized Impulse Response Function, South Africa

\section{Introduction}

Financial (Credit) organizations and banks are regarded as predominantly essential for the economic development and social welfare of an economy. Since the great depression of the 1930s, the world has never experienced the largest shock to the finance industry like the event of the 2007-2008 US Subprime Mortgage Crisis (SMC). The foundation of the financial industry was stunned by the SMC and hence causing the failure of many iconic Wall Street investment banks and prominent depository institutions (Petersen et al. 2012, cited in Meniago et al. 2013). Like Masilela (2009) asserted, 
the crisis could indeed be associated to a debt/credit crisis. In the year 2008-2009, the SMC tumbled into a financial crisis that spread into many regions of the world and was later commonly referred to as the Global Financial Crisis (GFC). Since the event of the GFC, we could see its adverse effects in many of the advanced economies in the world (especially American and European banks) and its contagion did not seem to have spared many emerging economies (like South Africa). Several reasons contributed to the incident of the crisis and we can largely draw the origin of the 2008 financial crisis to the lending behaviour of banks. Specifically, the GFC was triggered by superfluous liquidity and the involvement of American banks into unsafe lending which requires granting mortgage advances to debtors of low income capacity. Similarly, as a result of excess liquidity experienced during the crisis, many banks and other financial institutions began to fall resulting in high banking leveraging, low capital quality and extreme mounting credit. According to Georg (2011), the recent financial crisis revealed how crucial the breakdown of the interbank market is, as many banks faced difficulties to refinance themselves.

With the fear of contagion, anticipations about the negative impact of the financial crisis on African and developing countries began to arise (Naudé, 2009). However, from the point of view of several experts, it was postulated that financial institutions in the South African economy would not endure too much from the debt crisis. They based this argument on the fact that South Africa had minimal inclusion in the global economy and an insignificant exposure to the US subprime mortgage market as compared to the European banks. These conjectures that South Africa would be relatively unscathed by the crisis, soon became redundant when this economy was plunged into a recession for the first time in 17 years. In particular, South Africa experienced a significant devaluation of assets, tightening of financial conditions, shut down of companies, rise in unemployment, slow-down of economic growth and increased levels of household debt.

Since the occurrence of the GFC, South Africa has record inflated levels in its debt to income ratios compared to previous years. Such high levels of debt expose the household sector and leave the economy more vulnerable to various external shocks. In place of this, there is a greater incentive to maintain household debt at a reasonable level and to identify the factors which mainly contribute to the inconsistencies in the South African household debt.

In the main, this paper attempts to measure the long run elasticity of the South African household debt to shocks from real house prices, inflation, real income, real prime rate, gross domestic product (GDP), real household consumption and real household savings through the estimation of Vector Auto Regression (VAR). Thereafter, a Variance Decomposition analysis will be estimated to measure the relative importance of each random innovation in affecting the variables in the model. Finally, the Generalized Impulse Response Function (GIRF) analysis is employed to determine the impact of various external shocks on the level of household debt in South Africa. This study is relevant not only because it contributes to the literature, and to best of our knowledge, it is the first of its kind to employ the variance decomposition and the GIRF analysis to study the impact of shocks on household debt in South Africa.

This paper is organized as follows. The current section is introductory in nature. Section 2 considers an overview of the literature. Section 3 considers the data and the methodology adopted in this study. Section 4 discusses the results and we finally conclude the study with Section 5.

\section{Empirical Literature}

\subsection{Theoretical Model}

The theoretical outline of this paper is based on the framework of the Life Cycle Hypothesis (LCH) of Franco Modigliani. The author's main idea is that households set in for large debt amounts to smooth their expenditures and mainly to possess lifelong goods like houses, cars, etc. The LCH initially serves as a basis for the choice of variables in this study. In this regard, based on this framework, we choose to include house prices, inflation, consumer price index, household income, interest rate, economic growth, household consumption expenditures and household savings as variables which mainly contribute to the disparities in the level of household debt in South Africa.

\subsection{Empirical Literature}

In this paper, we consider the body of literature which investigates the impact of shocks on related variables using the Generalized Impulse Response Function (GIRF) analysis. Among them, Girardi and Paesani (2005) conducted an empirical investigation of the transfer problem for the Euro zone vis-à vis the rest of the world. They made use of the CVAR (VECM) approach and employed the GIRF to study the convergence speed towards a country's equilibrium 
position. The authors mentioned that GIRF analysis does not allow giving a structural interpretation to the impulses, but overcomes the model identification problem by providing a significant characterization of dynamic responses to typically observable shocks. In the same way to this approach, Hurley (2010) employed a generalized impulse response investigation to study the relationship between East Asian holdings of U.S securities and the U.S. short term and long term interest rates. The author also used the VECM approach to examine the dynamics and linkages in the variables. This analysis concluded that the low long-term rates in the U.S. may be explained in part by increased Asian holdings of the U.S. Consistent with these studies, a GIRF analysis will be utilize to trace the time paths of the effect of a typical shock in one variable on our remaining variables.

Kim (2011) investigated the relationship between household debt and aggregate income in the US using a growth Vector Autoregression Analysis (VAR). This study captures the transitory feedback among the growth rate of debt, GDP and net worth and observed that there exists a positive feedback process in the short-run between debt and aggregate income. One interesting feature of this paper is the use of the GIRF to study the impact of various shocks on the consumer debt. The author found that a shock to consumer debt is accompanied by an increase in consumption and Gross Domestic product (GDP) and similarly observed that investment as well as corporate debt permanently increases in response to a shock to consumer debt. Similarly, through the application of the VAR, we also employ the GIRF to study the response of household debt from external shocks in the South African economy.

Mukuddem-Petersen et al. (2010) employed the VAR model and GIRF to study speculative funding and its impact on subprime mortgage product pricing. They employed the GIRF analysis instead of the Impulse Response Function (IRF) to overcome the weakness related to the ordering of the variables and to ensure more robust results. They concluded that mortgage price is mostly affected by shocks from mortgage rates. Similarly, based on a VAR model, our study utilizes the GIRF approach to assess the impact of shocks to household debt in South Africa. Likewise, the GIRF was used in this paper to bypass the limitations faced by the IRFs.

\section{Data and Methodology}

\subsection{Data}

We employ quarterly time series data transformed into natural logarithms from the period 1985 Q1 to 2012 Q1. The variables used in this study includes the natural logs of real household debt to disposable income (LRHD), real house price index (LRHPI), consumer price index (LCPI), real income (LRIN), real prime rate (LRPR), real GDP (LRGDP), real household consumption expenditures (LRCON) and real household savings (LRSAV). Vis-à-vis the source of the data, The LRHPI data comes from the ABSA bank South Africa. As for the other variables, they are all sourced from the South African Reserve Bank (SARB) except for inflation (CPI) which was extracted from Statistics South Africa.

The regression equation of household debt will therefore be of the form:

$\mathrm{LRHD}_{\mathrm{i}}=\beta_{0}+\beta_{1} \mathrm{LRHD}_{\mathrm{i}}+\beta_{2} \mathrm{LRIN}_{\mathrm{i}}+\beta_{3} \mathrm{LCPI}_{\mathrm{i}}+\beta_{4} \mathrm{LRPR}_{\mathrm{i}}+\beta_{5} \mathrm{LRGDP}_{\mathrm{i}}+\beta_{6} \mathrm{LRCON}_{\mathrm{i}}+\beta_{7} \mathrm{LRSAV}_{\mathrm{i}}+\mu_{i}$

Through the application of the VAR, this paper constructs the Variance Decomposition for household debt to examine the input of the different variables in explaining the variation of household debt in South Africa. In addition, we employ the GIRF analysis to study the response of household debt to changes in LRHPI, LCPI, LRIN, LRPR, LRGDP, LRCON and LRSAV.

\subsection{Methodology}

To begin with, A VAR model will be estimated to examine the dynamics of our variables of interest. Thereafter, the dynamic effect of the VAR model is conveniently analysed by the Variance Decomposition and GIRF. These two analyses are both very good at forecasting.

\subsubsection{Variance Decomposition Analysis}

The Variance Decomposition also referred to as the Forecast Variance Decomposition, essentially denotes the breakdown of the forecast error variance for a particular time horizon. Explicitly, the Variance Decomposition separates the variation in an endogenous variable into the component shocks to the VAR/VECM. In essence, this analysis provides information about the relative importance of each random innovation in affecting the variables in the VAR/VECM (Ludi \& Ground, 2006; Georgantopoulos, 2012). Also, the Variance Decomposition can reveal which variables in the model has short term or long term impacts on another variable of interest (http://espin086.wordpress.com/2011/04/). Therefore, the 
main reason to conduct the Variance Decomposition is to obtain information about the relative significance of each random innovation in affecting the variables in the estimated model. Pesaran and Shin (1998) sustained that the Variance Decomposition analysis is very sensitive to the ordering of variables.

\subsubsection{Generalized Impulse Response Functions}

A shock to the $i$-th variable is also transmitted to all of the other endogenous variables through the dynamic (lag) structure of the VAR/VECM (Akanbi, 2011, Moniruzzaman et al., 2011). The $i$-th innovation is simply a shock to the $i$-th endogenous variable. An impulse response function traces the effect of a one-time shock to one of the innovations on current and future values of the endogenous variables. In other words, the Impulse Response Function (IRF) and the GIRF shows the effects of shocks on the adjustment path of the variables. This analysis is very useful especially when we want to access how shocks to economic variables resound through a system

In this paper, we use the GIRF proposed by Pesaran and Shin (1998) instead of the simple IRF because the latter presents several drawbacks. The results of the IRF are strongly affected by the ordering of the variables. This indicates that to get reliable and good results, we should order our variables properly and this might be a very difficult task. Consequently, the GIRF helps to overcome this difficulty by not requiring any ordering of variables. Another critique of the IRF is the omission of variables. Omitting important variables in the model may lead to major distortions in the IRF and having empirical results that is worthless (Lin, 2006).

For that reason, the GIRF is therefore employ in this study because we can construct an orthogonal set of innovations that are indifferent to the ordering of the variables. More robust results are expected with the computation of the GIRFs compared to using the ordinary IRFs.

Finally, we conclude that while the Variance Decomposition shows which shocks contributes the most in affecting the rest of the variables in the VAR, the GIRFs trace the effects of a shock to one endogenous variable onto the other variables in the estimated model.

\section{Empirical Results and Interpretation}

A complete VAR model was first assessed but as the coefficients of the estimated model are of very little use, they are not being reported. As a substitute, we report the outcome of the Variance Decomposition and GIRF analysis which are of vital importance to us. In the sequel, pertinent results are presented and discussed. However, before proceeding with interpretation of the dynamic analysis of household debt, it is quite interesting to investigate the behaviour of this variable "before", "during" and "after" the GFC.

\subsection{Analysis of Household debt "before", "during" and "after" the GFC}

The graphical representation of household debt to disposable income is presented in Figure 1.

Figure 1: Graphical Representation of Household debt "before", "during", "after" the GFC

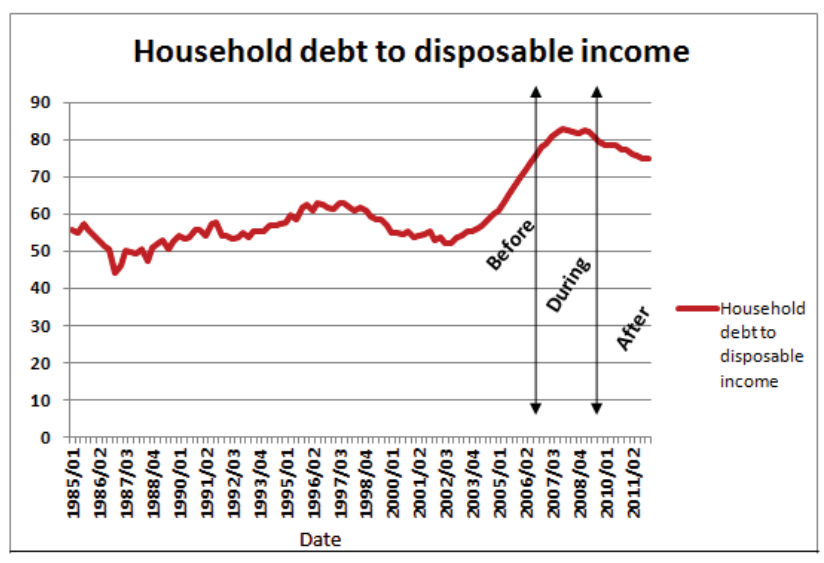


As the GFC hits many economies in the world, keeping the level of household debt at a balanced level has been of great concern among financial institutions. It is thus of crucial importance to this study to examine the trend of South Africa's household debt before, during and after the crisis. In Figure 1, we divide the graph in different segments/zones to analyze the periods "before", "during", and "after" the 2008-2009 financial crisis. In general, the period "before" the crisis (1985Q1 to 2007Q2) reveals that household debt steadily increases. From the year 02Q1 until 07Q2, the household debt experienced a drastic increase. A decrease in debt level is evident in the period "during" the crisis which includes the period 07Q3 to 09Q4. We observe this decline to be very minor as we could still observe household debt to be at a very high level. However, we tend to think that this slight decrease in household debt is due to several reasons related to stricter banking regulations which occurred in South Africa during that period of time. In this perspective, we highlight the implementation of the National Credit Act (NCA) in 2007 and we could possibly associate it effects on the decline of household debt during that year. The main purpose of the NCA in South Africa was to protect consumers against overindebtedness, exploitation and manipulation by the informal sector. From the above, we can possibly draw the conclusion that the US financial meltdown together with the NCA had a great influence on the trend behaviour of household debt in South Africa. As a result of the NCA, many households became more conservative and eager to consolidate their debt rather than make new debt.

After the crisis (from 2010 to date), the debt level continues to drop slowly. Nevertheless, household debt levels continue to be very high compared to preceding years. We observe that the US financial crisis affected the level of household debt in South Africa to a lesser extent compared to other countries in the world (especially the US and Europe). Nevertheless, this impact is still significant and contrary to some earlier predictions, that South Africa will not be affected by this crisis.

The dynamic behaviour of our estimated VAR model is analyzed using the following two approaches namely; the Variance Decomposition and the GIRF. The computation of these two analyses will not only be useful but will produce valid results in assessing how shocks to economic variables reverberate through the system and which macroeconomic variables greatly contribute in explaining the disparities in household debt.

\subsection{Variance Decomposition}

The Variance Decomposition of household debt over 5years computed in EViews is shown in Table 1.

Table 1: Variance Decomposition of Household Debt

\begin{tabular}{|c|c|c|c|c|c|c|c|c|c|}
\hline Period & S.E. & LRHD & LRHPI & LRIN & LCPI & LRPR & LRGDP & LRCON & LRSAV \\
\hline 1 & 5.318 & 100.000 & 0.000 & 0.000 & 0.000 & 0.000 & 0.000 & 0.000 & 0.000 \\
\hline 2 & 6.439 & 84.128 & 0.022 & 6.743 & 0.179 & 3.277 & 4.271 & 0.552 & 0.824 \\
\hline 3 & 7.026 & 72.009 & 0.363 & 11.573 & 0.546 & 5.611 & 7.222 & 0.465 & 2.207 \\
\hline 4 & 7.323 & 67.905 & 1.168 & 11.921 & 0.719 & 7.413 & 7.590 & 0.459 & 2.820 \\
\hline 5 & 7.558 & 65.507 & 2.396 & 11.259 & 0.859 & 8.851 & 7.502 & 0.465 & 3.157 \\
\hline 6 & 7.765 & 62.919 & 4.097 & 10.698 & 1.046 & 9.696 & 7.517 & 0.505 & 3.519 \\
\hline 7 & 7.967 & 60.059 & 6.296 & 10.422 & 1.251 & 9.845 & 7.645 & 0.626 & 3.851 \\
\hline 8 & 8.189 & 56.925 & 8.878 & 10.486 & 1.440 & 9.489 & 7.871 & 0.849 & 4.058 \\
\hline 9 & 8.450 & 53.474 & 11.632 & 10.817 & 1.607 & 8.915 & 8.260 & 1.173 & 4.119 \\
\hline 10 & 8.759 & 49.772 & 14.316 & 11.290 & 1.750 & 8.364 & 8.872 & 1.585 & 4.047 \\
\hline 11 & 9.118 & 45.981 & 16.719 & 11.800 & 1.866 & 7.982 & 9.715 & 2.062 & 3.872 \\
\hline 12 & 9.518 & 42.299 & 18.703 & 12.276 & 1.953 & 7.815 & 10.750 & 2.572 & 3.628 \\
\hline 13 & 9.946 & 38.890 & 20.226 & 12.671 & 2.012 & 7.837 & 11.915 & 3.087 & 3.357 \\
\hline 14 & 10.385 & 35.857 & 21.316 & 12.963 & 2.047 & 7.992 & 13.144 & 3.588 & 3.088 \\
\hline 15 & 10.820 & 33.239 & 22.039 & 13.147 & 2.060 & 8.223 & 14.376 & 4.066 & 2.845 \\
\hline 16 & 11.236 & 31.028 & 22.473 & 13.233 & 2.056 & 8.485 & 15.565 & 4.516 & 2.641 \\
\hline 17 & 11.625 & 29.189 & 22.690 & 13.233 & 2.038 & 8.748 & 16.679 & 4.939 & 2.479 \\
\hline 18 & 11.977 & 27.675 & 22.750 & 13.165 & 2.009 & 8.996 & 17.702 & 5.338 & 2.361 \\
\hline 19 & 12.291 & 26.436 & 22.696 & 13.046 & 1.973 & 9.221 & 18.625 & 5.715 & 2.284 \\
\hline 20 & 12.564 & 25.426 & 22.565 & 12.891 & 1.934 & 9.420 & 19.449 & 6.070 & 2.241 \\
\hline
\end{tabular}

Cholesky ordering: LRHD, LRHPI, LRIN, LCPI, LRPR, LRGDP, LRCON, LRSAV 
From Table 1, we depict the relative significance of each structural shock to the variables in the system. We then report here the variance decomposition of household debt over a 20 quarters period ahead. In terms of explaining its own shocks, $100 \%$ of household debt variance can be explained by its own innovation in the first period. We also observe that as time goes on; its contributions are progressively tumbling till it reaches $25.42 \%$ in the last quarter. However, it remains the highest contributions over the 5 years forecasted compared to the other variables. This brings us to the conclusion that over 5 years ahead, household debt disparities can be greatly explained by its own shocks.

Following household debt itself, the $2^{\text {nd }}$ up to the $8^{\text {th }}$ period demonstrates the relative importance of LRIN, LRPR, LRHPI and LRGDP in explaining the variation of household debt. As we can view in the second year, LRIN accounts for $10.48 \%$ in the variation of household debt, LRPR accounts 9.48\% while LRHPI and LRGDP accounts for $8.87 \%$ and $7.87 \%$ respectively. In lieu of the above, we draw conclusion that excluding household debt itself, in 2 years forward, variation in household debt levels are more influenced by disparities in LRIN, LRPR, LRHPI and LRGDP. Nevertheless, we observe a slightly different scenario from the $9^{\text {th }}$ quarter up to the last observed period of study. We scrutinize household debt levels to be mainly influenced by the variation in LRHPI. In the $10^{\text {th }}$ quarter, LRHPI accounts for $14.31 \%$ in the $10^{\text {th }}$ quarter compared to $22.56 \%$ in the last quarter which is a considerable increase. The contribution of LRHPI in explaining the variation of household debt remains the highest compared to other variables. As we observe, LRGDP accounts for $8.87 \%$ in the $10^{\text {th }}$ period to $19.449 \%$ in the last period. As for the rest of the variables, the variation in household debt is mainly associated with variations in LRIN, LRPR, LRCON, LRSAV and LCPI respectively. As observe in table 1 , in the $5^{\text {th }}$ year (20 th quarter), $12.89 \%$ of LRIN, $9.42 \%$ of LRPR, $6.07 \%$ of LRCON, $2.24 \%$ of LRSAV and $1.93 \%$ of LCPI explains the deviations in the level of household debt in South Africa.

With regard to the aforementioned interpretations, over a five year horizon, we can possibly associate disparities in the level of household debt in South Africa to be principally explained by the contributions in house prices, household income, gross domestic product and prime rate.

\subsection{Generalized Impulse Response Function (GIRF)}

The GIRF over 20 quarters from the VAR estimation is shown in Figure 2 and 3 . In this paper, considering the interpretation of the impulse results, the emphasis is placed on the response of household debt to shocks to the other variables and the response of other variables to a shock to household debt.

Figure 2: Response of Household Debt to Shocks to Other Variables

Response to Generalized One S.D. Innov ations

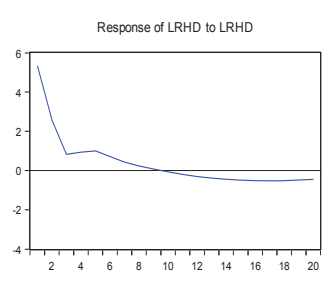

Response of $L R H D$ to $L R H P I$

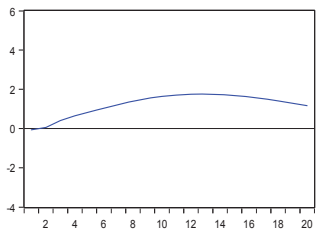

Response of LRHD to LRPR

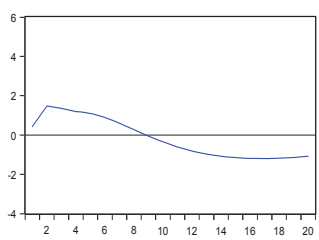

Response of LRHD to LRSAV
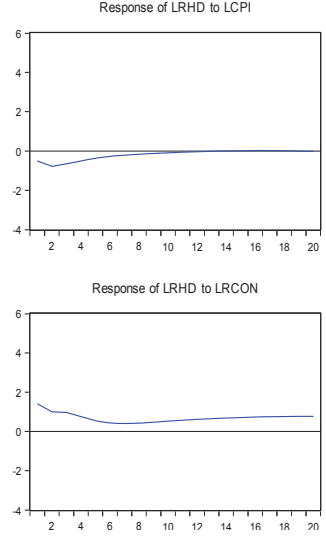

Response of LRHD to LRCON

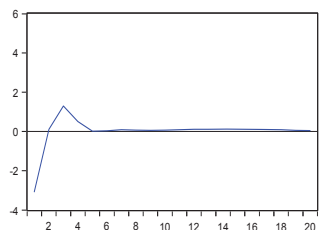

Response of LRHD to LRIN

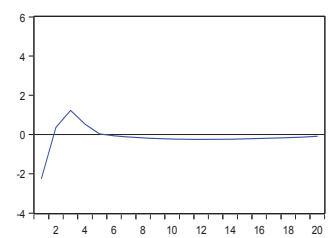

Response of LRHD to LRGDP

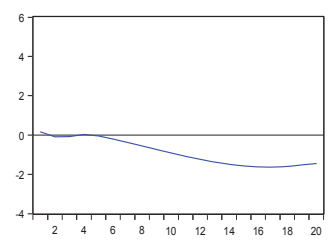


Figure 3: Response of Other Variables to a Shock to Household Debt

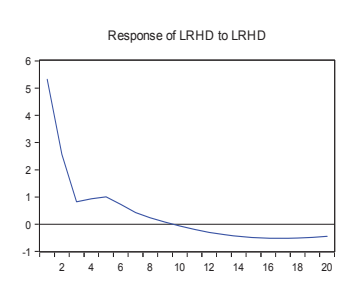

Response to Generalized One S.D. Innovations
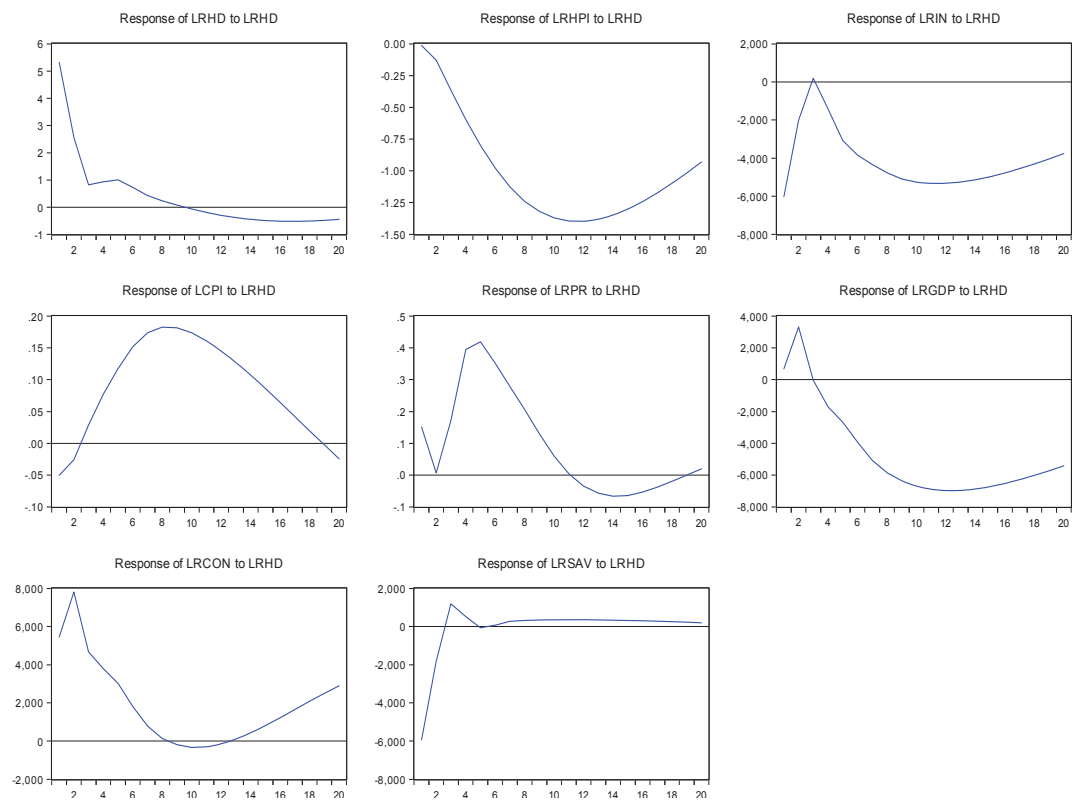

From Figure 2, the response of household debt to a shock to itself is seen to be significantly positive in the first $8^{\text {th }}$ quarters over the period of study. However, we observe an insignificant response from the $9^{\text {th }}$ to the $10^{\text {th }}$ quarter. From the $10^{\text {th }}$ until the last observed quarter, household debt is seen to respond negatively to a shock to itself.

Figure 2 reveals that the response of LRHD to shocks from LRHPI is seen to be insignificant in the beginning of the first two quarters. Afterwards, we notice that the response of debt is seen to be positive. This positive response allows us to justify the increase in the household debt in South Africa due to the event of the financial crisis. We also emphasize here that this response is as expected in the theory (the $\mathrm{LCH}$ ) which justifies that increases in house prices will cause household debt to increase as well. A propos, we rationalize that a positive standard deviation shock to LRHPI will cause the level of household debt to increase in South Africa.

Still from the results, a shock on income causes household debt to respond negatively at the start of the first quarter. Nonetheless, we detect a positive response from the middle of the $1^{\text {st }}$ quarter to the $5^{\text {th }}$ quarter. Afterwards, we notice a slightly insignificant response and later on the response turns negative until the last quarter. For that reason, we conclude that the response of household debt to a shock from income is perceived to have fluctuating behaviours.

Household debt is observed to respond negatively from the $1^{\text {st }}$ to the $9^{\text {th }}$ quarter from a shock in inflation $(\mathrm{CPI})$. Subsequently, household debt is seen to respond insignificantly. We then put forward the conclusion that a positive financial shock on the level of inflation will cause household debt to respond negative in the first gth $^{\text {th }}$ quarter and then its insignificant effect will be observed until the last observed quarter. Notwithstanding, we observe that a positive shock on prime rate causes household debt to respond positively from the $1^{\text {st }}$ until the $10^{\text {th }}$ quarter. The response is later on seen to be positive until the last quarter. Regarding the response of household debt to GDP, it is seen to be insignificant from till the $6^{\text {th }}$ quarter and then the response become negative. We also observe the response of household debt to be positive to a shock in consumption which brings us to the conclusion that a positive shock on household consumption will cause household to respond positively.

From the above discussions, the GIRF results validate that shocks from house prices, household consumption will cause household debt to respond positively in South Africa. However, the response of household debt shows fluctuating behaviours to shocks from household income, inflation, prime rate, gross domestic product and household savings.

Now we consider the interpretation of the response of other variables to a shock to household debt as shown in Figure 3. 
The outcome of the GIRF reveals that an adjustment in the level of household debt will cause house prices and household income to respond negatively throughout all the quarters. We terminated that a shock on household debt will cause house prices and household income to decrease. Unstable behaviours are seen in the response of some of the variables to a shock from household debt as seen in Figure 3. The responses of LCPI, LRPR, LRCON and LRSAV are irregular throughout the forecasted period of time as it is observe to either respond negatively and afterward positively and then vice versa

With the above explanations, we analyzed how household debt will respond from a shock in other variables and vice versa.

\section{Conclusion and Recommendations}

Historically it is evident that financial crises act as a source of devastating shocks to vulnerable economies. In this paper, through the estimation of the VAR model, we have applied the Variance Decomposition and the GIRF analysis over 20 periods ( 5 years) to examine the response of household debt to shocks. The macroeconomic variables considered in this paper are real house price index, consumer price index, real income, real prime rate, real gross domestic product, real household consumption expenditures and real savings; all expressed in natural logarithms form. The timeline for this study extends over the period 1985 Q1 to 2012 Q1.

The graphical inspection of household debt suggests that the US 2007 SMC which led to the 2008-2009 financial crisis affected the level of household debt in South Africa to a lesser extent. Before the period of the crisis, we observe household debt levels to be very high and continued to increase rapidly. During the period of the crisis, we notice that that the level of household borrowing kept on increasing and experienced a slight decrease but still remained very high. The implementation of the NCA in South Africa in 2007 suggests that the subsequent decrease in household debt in that period was not only caused by the SMC but also by the application of the aforementioned act.

The Variance Decomposition analysis was mainly employed in this paper to investigate which variables contribute mostly in explaining the variation in the level of household debt in South Africa. The outcome reveals that if we picture the level of household debt in a 5 year forecast period, its variation could largely be associated to changes house prices, household income, gross domestic and prime rate respectively.

Moreover, regarding the GIRF analysis, the outcome supports the following findings. The results clearly reveal the significant positive response of household debt to a shock from house prices and household consumption. These outcomes reflect the expectations from the theory. Nevertheless, the response of debt shows fluctuating behaviours to shocks from income, consumer price index, prime rate, GDP and household savings over the estimated period.

Based on the response of other variables to shocks from household debt, the analysis reveals that a shock in household debt will cause house prices and household income to respond negatively throughout all the quarters. The theory that rising household debt comes from a decrease in household income is just justified with this outcome. However, considering the response of household debt to shocks from income, inflation, prime rate, GDP and household savings, fluctuating behaviours were observed.

Based the strength and reliability of these results, we recommend its use to smooth the progress of decision making regarding the management of household debt levels in South Africa. We then propose the following recommendations.

The outcome reveals that a shock from house prices contributes to an increase in household debt levels. Accordingly, as housing debt characterizes the most important element of household debt in South Africa as well as in many other countries, we therefore advise closer and proper management of the housing market. Specifically, we recommend that the government ought to be meticulous relating to the issuing of new homes to households. The achievement of this task can possibly be done by the closely examination of the household's credit conditions. Considering this, we suggest that only households satisfying good credit conditions should be agreed homes. This will be very advantageous because implementing this will cause not only the money lenders to become more proficient in the issuing of new loans but the borrowers (households) will be disposed to extra responsibility when they enter in for debt. An attitude of keeping good credit conditions will consequently be developed among households and in return, this will decrease the level of household debt.

Gross domestic product and household consumption were found in both analyses to contribute significantly in the changes in household debt levels in South Africa. It is theoretically justified that higher GDP usually identified as a proxy of economic growth implies higher income. Higher economic growth in a country will certainly involve its benefits being enjoyed but it is unfortunate that often not all of the gains of economic growth are allocated likewise among individuals. It 
is important to note that South Africa for example fall among countries that possess the highest income disparity in the world. By this means, we emphasize on strategies to be develop the South African government to reduce the income inequality in the country so that the benefits of economic growth could be enjoyed by all and as such household debt will eventually be decreased. Notwithstanding, the theory also sustains the hypothesis that higher household consumption expenditures lead to increased household debt levels. In lieu of this, we ascertain that households are faced in with high debt level because of lack of income. For that reason, suitable concentration should be placed on how households use up their funds. We propose that household debt can be reduced if households spend carefully by meeting up strictly their basic needs. Debt reduction in the household sector can also be attained through the help of financial/debt counsellors who will thoroughly advise households in drawing up their monthly budget plan and assisting them in their expenditures strategies.

The outcome also reveals that household income contribute considerably in the changes of household debt levels in South Africa. Low income is undoubtedly the principal reason why households enter into debt. Unemployment, low paid jobs could be associated to the low income levels among households. We therefore recommend that the government should remedy the problem of unemployment by the creation of new jobs as it represents one of the main macroeconomic challenges in South Africa. By doing so, households will be found with more money in their pockets and will in turn make less debt. This allows us to postulate that debt in the household sector can be lowered if more jobs are created in the economy which consequently will drive more income among households.

For future research, we will like to encourage more national and international studies using this type of econometric approach in order to facilitate researchers in the interpretation and comparison of such economic relationships.

\section{References}

Akanbi, O. A. (2011). The Macroeconomic Determinants of Technical Progress in Nigeria. South African Journal of Economic and Management Sciences, 14(3), 282-297.

Allen, F., \& Giovannetti, G. (2010). Fragile Countries and the 2008-2009 Crisis, Working Paper, EUI-RSCAS.

Consumption Function retrieved at http://en.wikipedia.org/wiki/Consumption function

Debelle, G. (2004). Macroeconomic Implications of Rising Household Debt, Working Paper, Bank of International Settlements.

Debelle, G. (2004). Household Debt and the Macroeconomy. BIS Quarterly Review, 51-64.

Fixed and Variable mortgage rates retrieved at http://www. privateproperty.co.za/news/industry-news/fixed-and-variable-mortgage-rates

Georg, C. P. (2011). Basel III and Systemic Risk Regulation-What Way Forward. Working Papers on Global Financial Markets, No.17), Retrieved from http://www.gfinm.de/images/stories/workingpaper17.pdf

Georgantopoulos, A. G. (2012). Forecasting Tourism Expenditure and Growth: A VAR/VECM Analysis for Greece at both Aggregated and Disaggregated Levels. International Research Journal of Finance and Economics, 96, 155-167.

Girardi, A., \& Paesani, P. (2005). The Transfer Problem in the Euro Area: A cointegration Analysis. Retrieved from http://ssrn.com/abstract=835704.

Hurley, D. T. (2010). A Generalized Response Investigation of U.S Long and Short-Term Interest Yields and Asian Holdings of U.S. Treasuries. Journal of International and Global Economic Studies, 3(1), 168-86.

International Monetary Fund.2012, April. Chapter 3

Kim, K. Y. (2011). The Macroeconomic Implications of Household Debt: An Empirical Analysis. Working Paper, Trinity College, Department of Economics.

Laeven, L., \& Valencia, F. V. (2012). Systemic Banking Crises Database: An Update. Working Paper, International Monetary Fund.

Lin, J-L. (2006). Teaching Notes on Impulse Response Function and Structural VAR. 1-9.

Ludi, K. L., \& Ground, L. (2006). Investigating the bank-Lending Channel in South Africa: A VAR Approach. Working Paper, University of Pretoria, South Africa.

Masilela, E. (2009). South African Savings Institute chairman's statement at the occasion of the launch of savings month 2009. Johannesburg: The South African Savings Institute. Available at www.savingsinstitute.co.za.Accessed June 2012.

Meng, S., \& Hoang, T. N., \& SIRIWARDANA, M. (2011). The Determinants of Australia Household Debt: A Macro -Level Study. Working Paper, Business, Economics and Public Policy.

Meniago, C., Mukuddem-Petersen, J., Petersen, M. A., \& Mongale, I. P. (2013): "What Causes Household Debt to Increase in South Africa". Economic Modelling, 33, 482-492.

Modigliani, F., \& ANDO, A. (1957). Tests of the Life Cycle Hypothesis of Saving: Comments and Suggestions. Oxford Institute of Statistics Bulletin, 29, 99-124.

Modiglinai, F., \& Brumberg, R. (1954). Utility analysis and the consumption function: An interpretation of cross-section data in K.K. Kurihara (ed.): Post Keynesian Economics. Rutgers University Press, New Brunswick, NJ.

Modigliani, F., \& CAO, S. L. (2004). The Chinese Puzzle and the Life-Cycle Hypothesis. Journal of Economic Literature, 42, 145-170.

Moniruzzaman, M. D., Toy, M. M., \& HASSAN, A. B. M. R. (2011). The Export Supply Model of Bangladesh: An application of Cointegration and Vector Error Correction Approaches. International Journal of Economics and Financial Issues, 1(4), 163-171. 
Mukuddem-Petersen, J., Petersen, M. A., Bosch, T., \& B. De Waal. (2010). Speculative Funding and its Impact on Subprime Mortgage Product Pricing. Journal of Applied Financial Economics, 21(19), 1397-1408.

Naude, W. (2009). The financial crisis of 2008 and the Developing Countries. Working Paper, UNU-WIDER.

Pesaran, M. H., \& Shin, Y. (1998). Generalized Impulse Response Analysis in Linear Multivariate Models. Economic Letters, 58(1), 7-29. Petersen, M. A., Senosi, M. C., \& Mukuddem-Petersen, J. (2012). MUKUDDEM-PETERSEN, J. (2012). Subprime Mortgage Models. New York: Nova Science Publishers, 2012, ISBN: 978-1-61761-132-2 (ebook) 2011, ISBN: 978-1-61728-0 (Hardcover).

SARB. 2010. Annual Economic Report, Pretoria: South African Reserve Bank.

SARB. JUNE 2012. Quarterly bulletin, Pretoria South African Reserve Bank. Variance Decomposition available at (http://espin086.wordpress.com/2011/04/). 